\title{
PENGARUH PAPARAN ZAT PEWARNA BATIK TERHADAP KEJADIAN DERMATITIS KONTAK IRITAN PADA PEKERJA BATIK DI SURAKARTA
}

\author{
Reni Wijayanti ${ }^{1}$, Sumardiyono $^{1}$ \\ ${ }^{1}$ Fakultas Kedokteran, Universitas Sebelas Maret Surakarta \\ Email: reni31073@gmail.com \\ Email: sumardiyono@staff.uns.ac.id
}

\begin{abstract}
ABSTRAK
Dermatitis kontak iritan (DKI) dapat diderita oleh semua orang dari berbagai golongan umur, ras dan jenis kelamin. Jumlah penderita DKI diperkirakan cukup banyak terutama yang berhubungan dengan pekerjaan (DKI akibat kerja), namun dikatakan angkanya secara tepat sulit diketahui. Hal ini disebabkan antara lain oleh banyaknya penderita dengan kelainan ringan tidak datang berobat, atau bahkan tidak mengeluh. Tujuan penelitian ini adalah untuk menganalisis pengaruh paparan zat pewarna batik terhadap kejadian dermatitis kontak iritan pada pekerja batik di Surakarta. Penelitian menggunakan jenis observasional analitik dengan desain cross sectional. Populasi penelitian adalah pekerja batik di industri batik "Mahkota" dan "Merak Manis" di Surakarta. Teknik pengambilan sampel menggunakan consecutive sampling. Jumlah sampel 40 orang dengan kriteria masa kerja mimimal 1 tahun dan umur minimal 20 tahun. Pengambilan data penelitian dilakukan pada tanggal 4 Mei 2018. Alat ukur yang digunakan dalam penelitian ini adalah kuesioner dermatitis kontak iritan dan checklist. Variabel umur, masa kerja, dan pemakaian alat pelindung tangan digunakan kuesioner lembar isian data. Analisis data menggunakan Chi Square Test dengan perhitungan menggunakan software SPSS versi 23, pada taraf signifikansi 5\%. Faktor-faktor yang berhubungan dengan dermatitis kontak iritan pada pekerja batik adalah paparan zat pewarna $(p=0,007)$, pemakaian alat pelindung diri $(p=0,024)$, masa kerja $(p=0,044)$, umur $\left(X^{2}=0,048\right)$, dan jenis kelamin $(p=0,112)$. Kesimpulan penelitian ini adalah ada hubungan paparan zat pewarna batik terhadap kejadian dermatitis kontak iritan pada pekerja batik di Surakarta secara signifikan $\left(X^{2}=7,376 ; p=0,007 ;\right.$ OR $=6,78 ;$ C195\%: 1,59-28,86).
\end{abstract}

Kata kunci: Zat pewarna batik, Dermatitis kontak iritan, Pekerja batik

\section{PENDAHULUAN}

Salah satu tanggal penting bagi kebudayaan bangsa Indonesia adalah tanggal 2 Oktober karena pada tanggal itulah batik diakui sebagai warisan budaya dunia yang berasal dari Indonesia. Pengakuan batik sebagai warisan dunia ini berlaku sejak Badan PBB untuk Pendidikan, Keilmuan, dan Kebudayaan atau UNESCO, menetapkan batik sebagai Warisan Kemanusiaan untuk Budaya Lisan dan Non bendawi (Masterpieces of the Oral and the Intangible Heritage of Humanity) pada 2 Oktober 2009. Situs UNESCO mengatakan bahwa teknik, simbolisme, dan budaya terkait batik dianggap melekat dengan kebudayaan bangsa Indonesia. Bahkan, UNESCO menilai masyarakat Indonesia memaknai batik dari prosesi kelahiran sampai kematian (Galih, 2017). Menurut Alhusain (2015), batik merupakan salah satu produk tekstil hasil karya tradisional bangsa Indonesia. Hampir setiap daerah di Indonesia memiliki hasil karya batik dengan kekhasan motifnya. Ini merupakan salah satu dari sekian banyak ragam kekayaan bangsa yang perlu dilestarikan dan dijaga kualitasnya. Di Surakarta, batik merupakan hasil dari industri kecil dan menengah yang dikelola secara tradisional. Sebagian besar dari sumber daya manusia yang memproduksi kain batik memiliki kemampuan membatik secara turun-temurun. Dapat dikatakan bahwa membatik telah menjadi sumber mata pencaharian masyarakat Surakarta.

Salah satu lokasi industri batik di Surakarta adalah kecamatan Laweyan. Kampung Laweyan menjadi salah satu pusat batik yang tertua dan terkenal di Kota Solo setelah Kampung Batik Kauman. Kampung ini memiliki luas area 24, 83 hektar dan berpenduduk kira-kira 2500 penduduk di mana sebagian besar penduduknya bekerja sebagai pedagang ataupun pembuat batik. Kampung 
batik Laweyan sudah menjadi ikon batik Solo sejak abad ke-19 ketika asosiasi pedagang pertama kalinya dibentuk yaitu Sarikat Dagang Islam yang didirikan oleh Haji Samanhudi pada tahun 1912. Hingga sekarang 250 motif batik khas Kampung Batik Laweyan sudah dipatenkan. Berbeda dengan Batik Kauman yang cenderung berwarna gelap dan motif klasik, Batik Laweyan lebih menawarkan batik warna lebih terang (Dinas Pariwisata Kota Surakarta, 2018).

Dua diantara industri batik di kampung Laweyan Surakarta adalah industri batik "Mahkota" dan "Merak Manis", yang dalam proses kerjanya menggunakan tenaga kerja sebagai pelaksana. Jumlah pekerja pada kedua industri batik tersebut berjumlah lebih dari 40 orang. Pekerja batik tersebut umumnya secara langsung maupun tidak langsung berhubungan dengan bahan kimia berupa zat pewarna batik pada saat bekerja. Bahan kimia yang sering digunakan di industri batik mengandung natrium hidroksida $(\mathrm{NaOH})$, yang dikenal sebagai soda kausatik atau sodium hidroksida adalah sejenis basa logam kausatik yang sering digunakan di pabrik batik. Natrium Hidroksida terbentuk dari oksida basa. Kontak dengan bahan kimia, seperti pekerja pada industri batik dapat mengakibatkan berbagai kelainan kulit (Hudyono, 2002). Salah satu kelainan kulit akibat kontak dengan bahan kimia adalah dermatitis kontak iritan (DKI), yaitu efek sitotosik lokal langsung dari bahan iritan baik fisika maupun kimia, yang bersifat tidak spesifik, pada sel-sel epidermis dengan respon peradangan pada dermis dalam waktu dan konsentrasi yang cukup (Health and Safety Executive, 2004).

Dermatitis kontak iritan (DKI) dapat diderita oleh semua orang dari berbagai golongan umur, ras dan jenis kelamin. Jumlah penderita DKI diperkirakan cukup banyak terutama yang berhubungan dengan pekerjaan (DKI akibat kerja), namun dikatakan angkanya secara tepat sulit diketahui. Hal ini disebabkan antara lain oleh banyaknya penderita dengan kelainan ringan tidak datang berobat, atau bahkan tidak mengeluh (Djuanda et al., 2003). Oleh krena itu tujuan penelitian ini adalah untuk menganalisis hubungan paparan zat pewarna batik terhadap kejadian dermatitis kontak iritan pada pekerja batik di Surakarta.

\section{METODE}

Penelitian ini menggunakan jenis penelitian observasional analitik dengan desain cross sectional. Populasi penelitian adalah pekerja batik di industri batik "Mahkota" dan "Merak Manis" di Surakarta. Teknik pengambilan sampel menggunakan consecutive sampling, dimana semua subjek yang memenuhi kriteria dan bersedia menjadi responden dapat dijadikan responden penelitian sampai jumlah sampel terpenuhi. Jumlah sampel yang digunakan dalam penelitian ini adalah 40 orang dengan kriteria masa kerja mimimal 1 tahun dan umur minimal 20 tahun. Pengambilan data penelitian dilakukan pada tanggal 4 Mei 2018.

Alat ukur yang digunakan dalam penelitian ini adalah kuesioner dermatitis kontak iritan yang berisi 15 pertanyaan yaitu kejadian dalam hal: mengalami iritasi kulit dalam 1 bulan terakhir, iritasi timbul setelah bekerja, kulit bengkak, timbul kemerahan pada kulit, timbul vesikel kecil atau lepuhan dan akan mengeluarkan cairan bila terkelupas, terjadi pembentukan luka bila lepuhan terkelupas, lepuhan akan menyebar jika cairan dalam lepuhan terkelupas dan mengenai kulit yang tidak terkena sebelumnya, timbul rasa gatal, terasa sakit, terasa perih, terasa terbakar, lepuhan mengering kulit menjadi mengerut, kulit menjadi bersisik dan kering, terjadi penebalan pada kulit, dan kulit menjadi retak dan pecah-pecah. Data didukung dengan foto, dan untuk diagnosisnya dilakukan oleh dokter yang bersertifikat hiperkes. Variabel kontak dengan zat pewarna batik digunakan checklist melalui observasi langsung ke tempat kerja. Variabel umur, masa kerja, dan pemakaian alat pelindung tangan digunakan kuesioner lembar isian data. 
Analisis data menggunakan Chi Square Test dengan perhitungan menggunakan software SPSS versi 23, pada taraf signifikansi 5\%.

\section{HASIL DAN PEMBAHASAN}

Faktor-faktor yang berhubungan dengan dermatitis kontak iritan adalah jenis kelamin, usia, jenis pekerjaan, masa kerja, frekuensi paparan, penggunaan alat pelindung diri (sarung tangan), riwayat atopi, dan faktor mekanis (Afifah, 2012). Variabel faktor risiko yang berpengaruh terhadap dermatitis kontak iritan yang diukur adalah riwayat paparan zat pewarna batik, jenis kelamin, umur, masa kerja, dan kedisiplinan memakai alat pelindung diri (APD). Hasil pengukuran masingmasing variabel tersaji pada tabel 1 .

Tabel 1. Deskripsi statistik hasil penelitian $(n=40)$

\begin{tabular}{|c|c|c|c|c|c|c|c|c|c|c|c|}
\hline \multirow{3}{*}{ No. } & \multirow{3}{*}{ Variabel } & \multicolumn{6}{|c|}{ Dermatitis kontak iritan } & \multirow{3}{*}{$X^{2}$} & \multirow{3}{*}{$\mathrm{p}$} & \multirow{3}{*}{ OR } & \multirow{3}{*}{ CI95\% } \\
\hline & & \multicolumn{2}{|c|}{ Ya } & \multicolumn{2}{|c|}{ Tidak } & \multicolumn{2}{|c|}{ Jumlah } & & & & \\
\hline & & $\mathrm{n}$ & $\%$ & $\mathrm{n}$ & $\%$ & $\mathrm{~N}$ & $\%$ & & & & \\
\hline \multirow[t]{3}{*}{1.} & Paparan zat pewarna & & & & & & & & & & \\
\hline & Ada & 19 & 82,6 & 4 & 17,4 & 23 & 100 & 7,376 & 0,007 & 6,78 & $1,59-28,86$ \\
\hline & Tidak ada & 7 & 41,2 & 10 & 58,8 & 17 & 100 & & & & \\
\hline \multirow[t]{3}{*}{2.} & Jenis kelamin & & & & & & & & & & \\
\hline & Perempuan & 10 & 83,3 & 2 & 16,7 & 12 & 100 & 2,533 & 0,112 & 3,75 & $0,69-20,37$ \\
\hline & Laki-laki & 16 & 57,1 & 12 & 42,9 & 28 & 100 & & & & \\
\hline \multirow[t]{3}{*}{3.} & Umur (tahun) & & & & & & & & & & \\
\hline & $>33$ & 14 & 82,4 & 3 & 17,6 & 17 & 100 & 3,913 & 0,048 & 4,28 & $0,96-19,01$ \\
\hline & $\leq 33$ & 12 & 52,2 & 11 & 47,8 & 23 & 100 & & & & \\
\hline \multirow[t]{3}{*}{4.} & Masa kerja (tahun) & & & & & & & & & & \\
\hline & $>8$ & 12 & 85,7 & 2 & 14,3 & 14 & 100 & 4,062 & 0,044 & 5,14 & $0,95-27,70$ \\
\hline & $\leq 8$ & 14 & 53,8 & 12 & 46,2 & 26 & 100 & & & & \\
\hline \multirow[t]{3}{*}{5.} & Pemakaian APD & & & & & & & & & & \\
\hline & Tidak/ Kadang-kadang & 23 & 74,2 & 8 & 25,8 & 31 & 100 & 5,119 & 0,024 & 5.75 & $1.16-28,55$ \\
\hline & Rutin & 3 & 33,3 & 6 & 66,7 & 9 & 100 & & & & \\
\hline
\end{tabular}

Dalam bidang keselamatan dan kesehatan kerja, salah satu risiko kesehatan kerja atau penyakit akibat kerja dapat berupa penyakit kulit akibat kerja akibat terpapar bahan bahan iritan misalnya yang berhubungan dengan bahan kimia (Suma'mur, 2009). Menurut Taylor (2008), penyakit kulit akibat kerja disebut juga dengan penyakit kulit okupasi adalah kondisi abnormal kulit yang disebabkan karena kontak dengan substansi dan berkaitan dengan proses di lingkungan kerja. Penyakit kulit ini merupakan salah satu masalah kesehatan kerja karena dampaknya kronis dan berdampak pada ekonomi masyarakat dan karyawan. Harahap (2000) mendefinisikan dermatitis kontak sebagai suatu inflamasi pada kulit yang disertai dengan adanya edema intraseluler pada epidermis karena kulit berinteraksi dengan bahan-bahan kimia yang kontak dengan kulit, yang dapat digolongkan menjadi dermatitis kontak iritan dan dermatitis kontak alergi.

Pada tabel 1 terlihat ada hubungan yang signifikan antara riwayat paparan zat pewarna batik, umur, masa kerja, dan kedisiplinan memakai alat pelindung diri (pakaian kerja dan sarung tangan), sedangkan jenis kelamin memiliki hubungan yang tidak signifikan dengan kejadian dermatitis kontak iritan. Paparan zat pewarna memiliki faktor risiko yang paling besar diantara faktor lain $(\mathrm{OR}=6,78)$, sedangkan faktor risiko terkecil adalah jenis kelamin $(\mathrm{OR}=3,75)$.

Hasil penelitian ini menyatakan ada hubungan secara signifikan antara riwayat paparan zat kimia dengan dermatitis kontak iritan ( $\mathrm{p}=0,007$; OR $=6,78 ; 95 \% \mathrm{CI}: 1,59-28,86)$. Hasil penelitian 
yang sejalan dengan penelitian ini disampaikan oleh Afifah (2012), yang menyatakan ada hubungan yang bermakna antara frekuensi paparan bahan kimia dengan terjadinya dermatitis kontak iritan pada karyawan binatu $(\mathrm{p}=0,010)$, pada penelitian Afifah $(2012)$ pekerja yang kontak dengan bahan kimia mengalami dermatitis kontak iritan sebesar 42,9\%, sedangkan dalam penelitian ini sebesar 82,6\%. Demikian pula sejalan dengan penelitian Dinar (2016), yang menyatakan bahwa kontak bahan kimia ada hubungan dengan kajadian dermatitis kontak iritan pada pekerja salon $(\mathrm{p}=0,001)$.

Hasil penelitian ini menyatakan hubungan jenis kelamin dengan dermatitis kontak iritan secara ststistik tidak signifikan $(\mathrm{p}=0,112)$, namun $\mathrm{OR}=3,75$, sehingga dapat dinyatakan jenis kelamin perempuan memiliki risiko lebih besar daripada laki-laki untuk mengalami kejadian dermatitis kontak iritan. Hasil penelitian ini sangat mirip dengan hasil penelitian Afifah (2012) yang menyatakan jenis kelamin tidak berhubungan secara signifikan dengan kejadian dermatitis kontak iritan ( $\mathrm{p}=0,441)$, tetapi ditemukan besarnya risiko perempuan mengalami dermatitis kontak iritan sebesar 1,76 (95\%CI: 0,41 hingga 7,55). Sebaliknya hasil penelitian Indrawan et al. (2014), menyatakan ada hubungan antara jenis kelamin dengan kejadian dermatitis kontak iritan pada pekerja bagian premix $(p=0,017)$. Hal berbeda dinyatakan oleh Mausulli (2010), yang menyatakan tidak ada hubungan yang signifikan antara jenis kelamin dengan kejadian dermatitis kontak iritan serta tidak ada risiko kejadian dermatitis kontak iritan berdasarkan jenis kelamin (p $=1,000 ; \mathrm{OR}=0,727 ; 95 \% \mathrm{CI}$ : 0,04 hingga 12,52).

Hasil penelitian ini menyatakan ada hubungan secara signifikan antara umur dengan dermatitis kontak iritan ( $\mathrm{p}=0,048 ; \mathrm{OR}=4,28 ; 95 \% \mathrm{CI}$ : $0,96-19,01)$. Hasil penelitian yang sejalan dengan penelitian ini disampaikan oleh Indrawan et al. (2014), yang menyatakan ada hubungan antara umur dengan kejadian dermatitis kontak iritan pada pekerja bagian premix $(\mathrm{p}=0,003)$. Demikian juga sejalan dengan penelitian Indrawan et al. (2007), yang menyatakan juga bahwa ada hubungan yang bermakna antara umur dengan kejadian dermatitis kontak iritan $(\mathrm{p}=0,003$ pada pekerja bagian premix. Demikian juga sejalan dengan hasil penelitian Lestari dan Utomo (2007), yang menyatakan ada hubungan antara umur dengan kejadian dermatitis kontak iritan $(\mathrm{p}=0,042$; OR $=$ 2,82; 95\%CI: 1,14 hingga 7,02). Namun pada penelitian Lestari dan Utomo (2007) menunjukkan risiko yang berbeda, yaitu usia kurang dari 30 tahun (kelompok umur muda) lebih berisiko dibanding dengan kelompok usia lebih tua, dengan batasan 30 tahun. Namun hasil penelitian ini tidak sejalan dengan penelitian Afifah (2012) yang menyatakan tidak ada hubungan antara umur dengan kejadian dermatitis kontak iritan $(\mathrm{p}=0,833)$ dengan nilai $\mathrm{OR}=0,83$ (\%\%CI: 0,37 hingga 3,59). Pada penelitian Affifah (2012) batasan umur adalah kurang dari dan lebih dari 30 tahun, sedangkan dalam penelitian ini adalah kurang dari dan lebih dari 33 tahun. Penelitian ini tidak sejalan juga dengan penelitian Mausulli (2010), yang menyatakan tidak ada hubungan yang signifikan antara umur dengan kejadian dermatitis kontak iritan $(\mathrm{p}=1,000)$ pada batasan umur kurang dari dan lebih dari 31 tahun (OR =0,833; 95\%CI: 0,24 hingga 2,90). Demikian pula, penelitian ini tidak sejalan dengan penelitian Prasetyo (2014), yang menyatakan tidak ada hubungan antara umur dengan dermatitis kontak iritan pada pekerja konstruksi yang terpapar semen $(p=0,874)$.

Hasil penelitian ini menyatakan ada hubungan secara signifikan antara masa kerja dengan dermatitis kontak iritan ( $\mathrm{p}=0,044$; $\mathrm{OR}=5,14 ; 95 \% \mathrm{CI}$ : $0,95-27,70)$. Hasil penelitian yang sejalan dengan penelitian ini disampaikan oleh Dinar (2016), yang menyatakan bahwa masa kerja berhubungan dengan kajadian dermatitis kontak iritan pada pekerja salon $(\mathrm{p}=0,001)$. Namun hasil penelitian ini tidak sejalan dengan penelitian Afifah (2012) yang menyatakan tidak ada hubungan antara masa kerja dengan kejadian dermatitis kontak iritan $(p=0,384)$ dengan nilai $\mathrm{OR}=0,17$ 
(\%\%CI: 0,17 hingga 1,94). Pada penelitian Affifah (2012) batasan masa kerja adalah kurang dari dan lebih dari 1 tahun, sedangkan dalam penelitian ini adalah kurang dari dan lebih dari 8 tahun. Demikian pula, penelitian ini tidak sejalan dengan penelitian Prasetyo (2014), yang menyatakan tidak ada hubungan antara masa kerja dengan dermatitis kontak iritan pada pekerja konstruksi yang terpapar semen $(\mathrm{p}=0,083)$.

Hasil penelitian ini menyatakan ada hubungan secara signifikan antara pemakaian alat pelindung diri dengan dermatitis kontak iritan ( $\mathrm{p}=0,024$; OR $=5,75 ; 95 \% \mathrm{CI}$ : 1,16 - 28,55). Hasil penelitian tentang hubungan pemakaian alat pelindung diri dengan dermatitis kontak iritan yang sejalan dengan penelitian ini disampaikan oleh Dinar (2016), yang menyatakan bahwa ada hubungan antara pemakaian alat pelindung diri dengan kajadian dermatitis kontak iritan pada pekerja salon ( $\mathrm{p}=0,001)$. Namun hasil penelitian ini tidak sejalan dengan penelitian Afifah (2012) yang menyatakan tidak ada hubungan antara pemakaian alat pelindung diri dengan kejadian dermatitis kontak iritan ( $\mathrm{p}=0,251)$ dengan nilai $\mathrm{OR}=2,15$ (\%CI: 0,57 hingga 8,03). Pada penelitian Affifah (2012) hasil uji statistik tidak signifikan $(\mathrm{p}=0,251)$, namun ditemukan besar risiko pekerja mengalami dermatitis kontak iritan bagi pekerja tidak memakai alat pelindung diri sebesar 2,12. Hal ini berbeda dengan hasil penelitian ini, yang menyatakan ada hubungan signifikan secara statistik ( $\mathrm{p}=0,24)$ diikuti besar risiko pekerja tidak memakai alat pelindung diri untuk mengalami dermatitis kontak iritan adalah 5,75 (95\%CI: 1,16 hingga 18,55). Penelitian ini tidak sejalan juga dengan penelitian Mausulli (2010) yang menyatakan tidak ada hubungan antara pemakaian alat pelindung diri dengan kejadian dermatitis kontak iritan ( $\mathrm{p}=0,083$; OR $=0,405 ; 95 \% \mathrm{CI}$ : 0,27 hingga 0,59). Demikian pula, penelitian ini tidak sejalan dengan penelitian Prasetyo (2014), yang menyatakan tidak ada hubungan antara pemakaian alat pelindung diri dengan dermatitis kontak iritan pada pekerja konstruksi yang terpapar semen $(\mathrm{p}=1,000)$.

\section{KESIMPULAN DAN SARAN}

Ada hubungan paparan zat pewarna batik terhadap kejadian dermatitis kontak iritan pada pekerja batik di Surakarta $\left(X^{2}=7,376 ; p=0,007\right.$; OR =6,78; CI95\%: 1,59-28,86).

\section{Ucapan Terima Kasih (Acknowledgement)}

Penulis mengucapkan terima kasih kepada Kepala Lembaga Penelitian dan Pengabdian Kepada Masyarakat (LPPM) Universitas Sebelas Maret yang telah memberikan tugas dan pendanaan pengabdian kepada masyarakat, dan kepada Pimpinan Perusahaan Batik Mahkota dan Batik Merak Manis Surakarta yang telah memberikan ijin lokasi kegiatan.

\section{REFERENSI}

Afifah, A. Faktor-Faktor Yang Berhubungan Dengan Terjadinya Dermatitis Kontak Akibat Kerja Pada Karyawan Binatu, Laporan Hasil Karya Tulis Ilmiah. Semarang: Fakultas Kedokteran, Universitas Diponegoro, 2012.

Alhusain, A. S. Kendala dan Upaya Pengembangan Industri Batik di Surakarta Menuju Standarisasi. Jurnal Ekonomi \& Kebijakan Publik, Vol. 6, No. 2, Desember 2015 199-213.

Dinar, V. R. M. Faktor-Faktor yang Mempengaruhi Kejadian Dermatitis Kontak Akibat Kerja Pada Karyawan Salon di Kelurahan Pahoman Bandar Lampung, Skripsi. Bandar Lampung: Fakultas Kedokteran, Universitas Lampung, 2016.

Dinas Pariwisata Kota Surakarta. Kampung Batik Laweyan. http://pariwisatasolo.surakarta.go.id/wisata/kampung-batik-laweyan. Diakses: 1 Agustus 2018. 
Djuanda, A., Hamzah, M., Aisah, S. Ilmu penyakit kulit dan kelamin. Edisi ke-6. Jakarta: Fakultas Kedokteran Universitas Indonesia. 2011. p. 3-4, 7-8.

Galih, B. 2 Oktober 2009, UNESCO Akui Batik sebagai Warisan Dunia dari Indonesia. 02/10/2017. https://nasional.kompas.com/read/2017/10/02/08144021/2-oktober-2009unesco-akui-batik-sebagai-warisan-dunia-dari-indonesia.

Harahap M. Ilmu penyakit kulit. Jakarta: Hipokrates; 2000. p. 22-26.

Health and Safety Executive, Contact Dermatitis in Workers. Available from: http://www.hseSkin_at_work_Work-related_skin_disease-Contactdermatitis.mht.hsebooks.co.uk. 2004. [Diakses 10 Mei 2018]

Hudyono J. Dermatosis akibat kerja. Majalah Kedokteran Indonesia, November 2002. 49(9), p. $16-23$.

Indrawan, I. A., Suwondo, A., Lestantyo, D. Faktor-Faktor Yang Berhubungan Dengan Kejadian Dermatitis Kontak Iritan Pada Pekerja Bagian Premix Di PT. X Cirebon, Jurnal Kesehatan Masyarakat (e-Journal), 2(2), Pebruari 2014, p. 110-118. http://ejournals1.undip.ac.id/index.php/jkm.

Lestari, F., Utomo, H. S. Faktor-Faktor yang Berhubungan dengan Dermatitis Kontak Pada pekerja di PT Inti Pantja Press Industri, Makara Kesehatan, 11(2), Desember 2007, p. 61-68.

Mausulli, A. Faktor-Faktor yang Berhubungan dengan Dermatitis Kontak Iritan Pada Pekerja Pengolahan Sampah di TPA Cipayung Kota Depok Tahun 2010. Jakarta: Fakultas Kedokteran dan Ilmu Kesehatan, Universitas Islam Negeri Syarif Hidayatullah, 2010.

Prasetyo, D. A. Faktor-Faktor yang Berhubungan dengan Dermatitis Kontak Iritan Pada Tangan Pekerja Konstruksi yang Terpapar Semen di PT. Wijaya Kusuma Contractors Tahun 2014. Jakarta: Fakultas Kedokteran dan Ilmu Kesehatan, Universitas Islam Negeri Syarif Hidayatullah, 2014.

Suma'mur. 2009. Hiegiene Perusahaan dan Keselamatan Kerja (Hiperkes). Jakarta: CV Sagung Seto, p. 310.

Taylor JS, Sood A, Amado A. Occupational skin diseases due to irritans and allergens.

Fitzpatricks et al, editors. Dermatology in general medicine, vol. $27^{\text {th }} \mathrm{ed}$. New York: McGraw Hill Medical; 2008. p. 2067-2073 